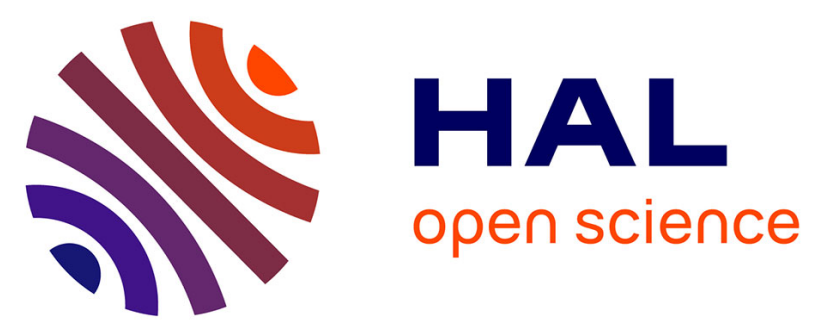

\title{
Tree influence on soil biological activity: what can be inferred from the optical examination of humus profiles?
}

Keiko Mori, Nicolas Bernier, Takashi Kosaki, Jean-François Ponge

\section{To cite this version:}

Keiko Mori, Nicolas Bernier, Takashi Kosaki, Jean-François Ponge. Tree influence on soil biological activity: what can be inferred from the optical examination of humus profiles?. European Journal of Soil Biology, 2009, 45 (4), pp.290-300. 10.1016/j.ejsobi.2009.05.001 . hal-00494621

\section{HAL Id: hal-00494621 \\ https://hal.science/hal-00494621}

Submitted on 7 Aug 2010

HAL is a multi-disciplinary open access archive for the deposit and dissemination of scientific research documents, whether they are published or not. The documents may come from teaching and research institutions in France or abroad, or from public or private research centers.
L'archive ouverte pluridisciplinaire HAL, est destinée au dépôt et à la diffusion de documents scientifiques de niveau recherche, publiés ou non, émanant des établissements d'enseignement et de recherche français ou étrangers, des laboratoires publics ou privés. 


\title{
Tree influence on soil biological activity: What can be inferred from the optical examination of humus profiles?
}

\author{
Keiko Mori ${ }^{a, *}$, Nicolas Bernier ${ }^{b}$, Takashi Kosaki ${ }^{c}$, Jean-François Ponge ${ }^{b}$

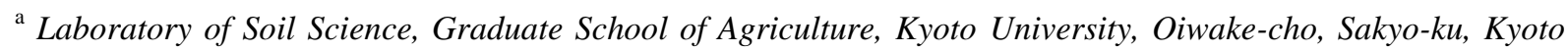 \\ 606-8502, Japan
}

${ }^{\mathrm{b}}$ Museum National d'Histoire Naturelle, Laboratoire d'Ecologie Générale, 4 avenue du Petit-Château, 91800 Brunoy, France

${ }^{\mathrm{c}}$ Graduate School of Global Environmental Studies, Kyoto University, Kyoto 606-8501, Japan

\begin{abstract}
Humus forms may vary in different forest stands, but the local influence of trees upon soil microbial and faunal activities is still imperfectly known. Optical methods could help to discern processes of litter transformation and formation of organo-mineral assemblages, allowing a better diagnostic of tree influences upon humus-soil development. The microstratification of humus was studied under a beech (Fagus crenata), a mixed oak forest (Quercus crispula and Quercus serrata), and a cedar (Cryptomeria japonica) plantation. The three sites are located in Kyoto Uapan), and share similar environmental conditions. Litter decomposition rates and soil fauna were also investigated. At the beech site, which had the thickest 0 horizon, the main process was the gradual fragmentation of litter. This process, together with shallow root and weak fungal development, gave rise to a stable sandwich-like structure in the O horizon. In contrast, the oak site showed a two-step transformation of litter. Initially, litter decomposition was triggered by the activity of white rot fungi, and the discarded litter decayed much more slowly thereafter. The cedar site exhibited a sharp vertical delineation between upper thick Oe horizon developed since plantation time and a relict A horizon. The optical method thus demonstrated differences in soil biological activities and litter transformation patterns under the three sites.
\end{abstract}

\footnotetext{
${ }^{*}$ Corresponding author at: Saitama Museum of Rivers, 39 Kosono, Yorii-machi, Saitama 369-1217, Japan. Tel.: +8148 581 8739; fax: +81485817332. E-mail address:keiko_mori@river-museum.jp (K. Mori).
} 
Keywords: Humus form; Micromorphology; Soil fauna; Litter transformation

\section{Introduction}

The humus form can be defined as a group of organic horizons and organo-mineral horizons, assembled according to the influence of soil biological activities, leading to humification and incorporation of organic material within a mineral matrix. The careful examination of a humus profile by optical methods may inform us about the main biological processes, which take place in the transformation of organic and mineral matter $[3,20,21]$. Traces of past events may also be detected through the careful examination of successive layers of accumulated organic matter [6].

In Japan, parent material, climate, landform and vegetation are interwoven in a complex manner providing diverse conditions for different humus form development [29,33]. Although vegetation has a great influence on nutrient dynamics $[8,11,13,22,23]$, a change in vegetation often occurs in relation to parent materials and topography. Thus the relationship of vegetation to humus form is often submerged in topographic factor $[16,27]$ making it difficult to differentiate the influence of vegetation on humus form development from that of the other factors in a semi-natural environment.

It is naturally postulated that different vegetation leads to different humus form. However, biological interaction involved within is required to be clarified for the better understanding of humus development. In the present study, we focused on differences in moder humus profiles driven by different forest types in similar environmental conditions as a case study to describe small-scale interactions. Our aim is to demonstrate how different vegetation types, (i.e. overall litter characteristics) influence underground biological activities and the transformation of litter, leading to different humus form development. To achieve this aim, we used an optical method standardized by Bernier and Ponge [6]. This method has been shown to be an useful tool to describe litter transformation patterns under the influence of both microbiological and faunal activities $[5,20]$.

Firstly, site characteristics related to vegetation, including litter accumulation, litter turnover rate, and initial decomposition rate, were investigated. Secondly, humus form was optically examined with the support of soil faunal investigation. 


\section{Materials and methods}

\subsection{Study sites}

The three study sites are located within close proximity of about $2 \mathrm{~km}$ on upper slopes near ridges of a forested mountain in Miyazu, Kyoto prefecture, Japan, under a cool temperate climate. In all three sites the soils developed on sedimentary rocks of mainly conglomerates [15]. Forest stands are (i) a beech-dominated stand (Fagus crenata BI.), (ii) a stand dominated bya mixture of two oak species (Quercus crispula var. grosserata (BI.) Miq and Quercus serrata Thunb) and (iii) a 45-yr-old plantation of Japanese cedar (Cryptomeria japonica (Lf.) D. Don). These sites will be referred to as Beech, Oak, and Cedar sites, respectively. The ground is covered by dwarf bamboo (Sasa kurilensis (Rupr.) Makino et Shibata), heavily at the Beech and the Oak sites and very sparsely at the Cedar site.

\subsection{Aboveground biomass, and litter fall, accumulation, and decay}

The aboveground tree biomass was estimated using the formula by Shidei and Kira [25] using measurements of diameter at breast height and tree height. The formula was gauged at the nearby Ashiu experimental forest. The biomass of dwarf bamboo was estimated by measuring the height of shoots, which was converted to weight by using ratio of shoot height to weight as determined for each site. The amount of litter fall was measured with litter traps for 4 years at the Beech and the Oak sites and for 2 years at the Cedar site with 510 replicates. Bamboo litter fall was measured for a single year, in an area of 1 x $2 \mathrm{~m}$ with 5 replicates in each site. Litter accumulation was determined by measuring the dry mass of accumulating organic matter (O horizon) taken from an area of $25 \times 25 \mathrm{~cm}$ with 3 replicates at each site. Litter turnover rate was estimated by dividing litter accumulation by the amount of litter fall.

Leaf litter was collected from each site in November 1997 and air-dried. Coarse $(2 \mathrm{~mm})$ and fine $(0.1$ $\mathrm{mm}$ ) nylon-mesh litterbags of $15 \times 15 \mathrm{~cm}$ were prepared and a dry weight of $6.75 \mathrm{~g}$ of litter was confined in each of them. Coarse mesh size allows entering of macrofauna in the sites (e.g. earthworms and diplopods), and mesoand microfauna while fine mesh size excludes macrofauna. Beech litterbags were placed on the ground surface at all three sites, while mixed oak (two oak species) litterbags were placed at the Beech and the Oak sites. Cedar litterbags were placed at the Cedar site only. A sampling plot of 10 x $3 \mathrm{~m}$ was divided to 5 sub-plots. Ninety 
litterbags for each litter species were placed in December1997. Litterbags were collected 4 times in 1998, 3 times in 1999, twice in 2000 with 4-5 replicates (one from each sub-plot) at each sampling occasion. After collection, the contents of each litterbag were dried and weighed for the calculation of weight loss. Decomposition rate was estimated with the decay constant of the equation $\mathrm{X}=e^{-k t}$; where $\mathrm{X}$ is the weight of litter, $k$ is the decay constant and $t$ is the time in years. Differences in weight loss rates were assessed by ANOVA (SPSS Inc. 1998).

\subsection{Microscopic observation of humus components}

The nomenclature of soil horizons follows that of the Soil Survey Manual [26] where the organic horizon (O horizon) is subdivided into $\mathrm{Oi}$, Oe, Oa horizons which are equivalent of $\mathrm{L}, \mathrm{F}$ and $\mathrm{H}$ horizons and the first mineral horizon rich in organic matter is referred to as A horizon.

A single humus sample was collected from each site in November 2000, representing the site. O horizons and part of the A horizon were cut vertically in order to isolate a column of $5 \times 5 \mathrm{~cm}$ in cross-section. In the field, they were separated into horizontal layers from top to bottom at $0.5-2 \mathrm{~cm}$ intervals depending on changes in their appearance, including at least $5 \mathrm{~cm}$ of organo-mineral A horizon. Each sample was immersed in 99\% ethyl alcohol immediately after sampling and brought back to the laboratory. Observation followed the point count method developed by Bernier and Ponge [6]. Samples were placed in petri dishes, immersed in 99\%

alcohol and covered by a transparent sheet with dots at regular intervals. Humus components were identified and counted at $4.5 \mathrm{x}$ to $40 \mathrm{x}$ magnification with a dissecting microscope. Humus components were first discriminated into broad categories then subdivided into detailed categories as shown in Table 1. For some categories, size classes were also recorded. Some humus components (e.g. leaves, organo-mineral materials) were picked to study their inner micromorphology. The samples were fixed with an acrylic monomer, sliced and observed under a light microscope (magnification up to 400x).

\subsection{Soil fauna}

At each site, macrofauna (macroarthropods and earthworms) were sampled on three occasions, in September 2000 (earthworms only), in October 2001, and in July 2002. On each occasion, three replicate 
samples covering an area of $50 \times 50 \mathrm{~cm}$ were taken by the hand sorting method down to the first $10 \mathrm{~cm}$ of the mineral horizon. Enchytraeida were collected by hand sorting in October 2001 from three 25 x $25 \mathrm{~cm}$ areas down to $5 \mathrm{~cm}$ depth. Width and length of individuals were measured for the estimation of their biovolume. Mesofauna were sampled in May, July, September and November 1998 with 7-10 replicates with a cylindrical core of 25 $\mathrm{cm}^{2} \times 8 \mathrm{~cm}$. The core was subdivided into two $4 \mathrm{~cm}$ depth samples for extraction with a Macfadyen's high gradient extractor. Soil mesofauna were identified under a light microscope at 40-400 x magnifications.

The biomass of saprophages was estimated by multiplying dry biomass by the ratio of the saprophages [24]. The dry biomass of saprophagous macrofauna was calculated according to the wet (fresh) weight to dry weight ratio used by Tsukamoto [32] and Shaefer and Schaurman [24]. The dry biomass of enchytraeids was estimated using data of volume weight ratio of Abrahamsen [1] and Edwards [10], and for Collembola and Cryptostigmata, the median dry weight given by Peterson and Luxton [18] was used. The ratios of saprophages for Oligochaeta, Isopoda (Crustacea), Diplopoda, Diptera larvae, Gastropoda, Lepidoptera, and Enchtytraeida are $1,0.75,1,0.75,1,1,0.75$ respectively $[24,32]$. The ratio of saprophages was assumed to be 1 for Collembola and Cryptostigmata. Differences in number and biomass were assessed by ANOVA (SPSS Inc. 1998).

\section{Results}

\subsection{Aboveground biomass, and litter fall, accumulation, and decay}

Aboveground biomass, litter fall, litter accumulation, litter turnover rate and decay constant (as decomposition rate) are shown in Table 2. The highest aboveground total biomass was found at the Cedar site followed by the Oak and the Beech sites. The higher aboveground biomass at the Cedar site was consistent with its higher level of litter production. In contrast, the litter turnover rate, which indicates the overall turnover rate of litter, was lowest at the Beech site and highest at the Oak site. Similarly, the litterbag experiment showed that the decomposition rate of leaf litter was lowest for beech leaves followed by cedar and oak leaves (Table 2). A significant difference $(\mathrm{P}<0.01)$ was found in the weight of remaining litter at the end of 3 -yr experiment between beech litter in the Beech site and oak litter in the Oak site for the coarse mesh size. There was no difference in decomposition rates between the two mesh sizes for all litter species at any of the sites nor between litterbags of the same species placed at different sites. 


\subsection{Humus micromorphology}

\subsubsection{Stratification}

Fig. 1 shows the vertical distribution of broad categories of humus components in the three humus profiles sampled at the three sites. The Beech site exhibited the thickest $\mathrm{O}$ horizon (Oi was $1 \mathrm{~cm}$, Oe was $6 \mathrm{~cm}$ and $\mathrm{Oa}$ was $3 \mathrm{~cm})$. The Oak and the Cedar sites had comparable depths of bulk 0 horizons $(5-5.5 \mathrm{~cm})$ but with a thicker Oe horizon at the Cedar site and a thicker Oa horizon at the Oak site. Apart from a thick accumulation of dead leaves, the Beech site exhibited a high proportion of other plant materials, especially in deeper horizons. This was attributed to a longer duration against degradation for branches and bud scales.

\subsubsection{Litter transformation}

At the Beech site, leaves and leaf fragments were mostly brown, poorly modified and large in size in the Oi horizon (Fig. 2a) and there was little evidence of any change in their appearance in the Oe horizon (Fig. 3). Bleaching of litter was hardly observed in the upper Oe horizon and could not be recorded at the resolution of the point count method. The microscopic observation of fragmented leaves at the Beech site revealed that their structure was well preserved in the Oe horizon. Melanized hyphae were observed running on the epidermis of leaves but the wall of mesophyll cells was not penetrated by hyphae, and cytoplasm was well-preserved with the appearance of spherical bodies of leaf-browning substances (Fig. 2b). Grazing and skeletonization of leaves due to faunal activity were hardly observed and veins and petioles showed only a slight increase in the upper Oa horizon (Fig. 3). Size and proportion of leaves shifted gradually from large to small, indicating a very gradual fragmentation and transformation of beech leaves (Fig. 3).

In the Oak site, leaves did not accumulate in thick layers. They were considerably bleached due to the development of white rot fungi in the very first layer (Fig. 3). Bleaching became less obvious as depth increased (Fig. 2c). In the lower Oe horizon, the size of leaf fragments decreased abruptly and the proportion of grazed and skeletonized leaves increased. The relative abundance of veins and petioles in the lower Oe horizon and in the Oa horizon (Fig. 3) testified that these components of leaf litter were less palatable than other leaf tissue. A similar pattern of litter transformation was observed in the deciduous leaves found at the Cedar site (Fig. 3). 
In contrast with the two deciduous sites, at the Cedar site, needles were the main component (around $40 \%$ ) of the thick Oe horizon (Fig. 1). Breakdown of cedar needle started with detachment from the stem and blackening at the transition between Oi and Oe horizons (Fig. 3). Needle bases became more frequently broken, and the fragmentation level (for needles) or the breaking level (for needle bases) increased gradually with depth (Fig. 3). The fragmentation of cedar needles was accompanied by scars of earthworm biting (Fig. 2d). Microscopic examination showed evidence of the development of melanized fungi, not only creeping on the cuticular surface of the needles, but also penetrating epidermis cells (Fig. 2e). Leaf darkening was probably not only an oxidative process of needle cell components but also the consequence of the intrusion of melanized fungi into the epidermis $[19,28]$. Melanized fungi were also observed in free spaces in mesophyll and phloem but cell walls remained rigid (Fig. 2f).

\subsubsection{Faeces and aggregates in organic and mineral horizons}

Oi to Oe horizons of the three sites were dominated by faeces of macrofauna (earthworms, Diplopoda, Crustacea, and Diptera larvae) and faeces of Enchytraeida were usually associated with earthworm faeces in these horizons.

In the Oe horizon of the Beech site, soil fauna dropped their faeces in the spaces between leaves. The result of this accumulation of faecal material filling up spaces between decaying leaves was a coherent structure consisting mainly of an alternation of leaves and faeces referred as sandwich-like structure (Fig. $2 \mathrm{~g}$ ). In the Oi and in the upper Oe horizons, faeces were still poorly compacted and could thus be attributed to taxa such as earthworms, Collembola and Cryptostigmata either observed as smears over leaf surfaces (Fig. 2a) or as a glue that adheres leaves with one another (Fig. 2g). As accumulation proceeded, faeces became coalescent and progressively lost their original shape (Fig. 2h). Such sandwich-like structures constituted the bulk of the thick Oe horizon at the Beech site. Small leaf fragments (Jess than $100 \mu \mathrm{m}$ ) included within the sandwich-like structure (Fig. 2i) may have been ingested then excreted. On the other hand, larger leaf fragments (larger than 1 $\mathrm{mm}$ ) were considered to be the remains of leaf consumption, giving evidence that the structure remained without disturbance. As decomposition proceeded, leaves included into sandwich-like structures gradually disappeared (Fig. $2 \mathrm{j}$ and k). Dark coloured and compact organic aggregates that accumulated in the Oa horizon (Fig. 4) were likely inherited from sandwich-like structures due to humification and ageing of the material. Remaining organic 
faeces and aggregates were relatively large in size (Fig. 5). In the Oa/A transition of the Beech site, we observed the coexistence of dark and light-coloured organo-mineral earthworm faeces (Fig. 21) giving evidence of a variation in earthworm diets. The coexistence of organic-rich and organic-poor materials was also observed within the same faeces, demonstrating that the diet of an individual could change dramatically (Fig. 2m). The surface of earthworm faeces was often rugose depicting grazing and tunneling activity by Enchytraeida (Fig. 2n). They left behind minute faeces either on the surface or filling up the space as they tunnelled into earthworm faeces (Fig. 2n and 0), as already observed in agricultural soils by Topoliantz et al. [30]. The A horizon was characterized by an abrupt decrease in the contribution of organic materials and by a concomitant increase in more compact organo-mineral aggregates (Fig. 4). At this depth, aggregates were mostly issued from the coalescence of different old earthworm faeces.

At the Oak site, the increase in organic faeces observed in the lower Oe horizon (Fig. 4) was concomitant with an abrupt change in the size and aspect of leaf fragments (Fig. 3). Unlike the Beech site, leaves were actively consumed by soil fauna (Fig. 2c) and fragmented litter and faeces poorly adhered together. Faecal components were mostly non-coalescent and small in size in the Oe and in the upper Oa horizons (Fig. 5). The Oa horizon was characterized by the accumulation of organic faeces made of both coarsely and finely comminuted organic materials. The majority of faeces was those of earthworms or Diplopoda (Fig. 2p, q). The A horizon of the Oak site was characterized by a high percentage of dark-coloured organo-mineral material (Fig. 4).

At the Cedar site, most of the organic faecal material in the Oe horizon (mostly from earthworms, enchytraeids and millipedes) was poorly humified. Cryptostigmata, and less often Enchytraeida, penetrated cedar needles, feeding on the parenchyma and dropping their faeces inside (Fig. 2r). The epidermis was discarded from ingestion so very little external indication of decomposition was visible. At the end of the process, the weakened epidermis collapsed. In the lower Oe horizon, organic faeces coalesced, sometimes moulded around cedar needles. In the upper Oe horizon, small amount of organo-mineral materials were observed. The A horizon of the Cedar site was characterized by a compact mineral matrix juxtaposed with a small amount of dark-coloured faeces, probably from earthworms (Fig. 4). Large aggregates observed in the A horizon were formed by compaction of faecal material but apart from these aggregates, the size of faeces or aggregates tended to be small (Fig. 5). 
In the Beech and Cedar sites, total tree roots reached the maximum abundance in the upper Oa horizon, while they had a relatively constant distribution from lower Oe to A horizons at the Oak site. The percentage of live tree roots was higher at the Beech site than at the other two sites. At the Beech site, the ratio of living fine roots to total roots was characteristically high in the upper $\mathrm{O}$ horizon where roots often adhered tightly to leaf surfaces (Fig. 6g). Mycorrhizal apices were mainly found in the lower Oe horizon, from the lower Oe horizon to the upper Oa horizon, and in the upper Oe horizon at the Beech, Oak and Cedar sites, respectively with the highest percentage found at the Beech site.

\subsection{Soil fauna}

At all three sites, earthworms had the highest biomass among the saprophagous macrofauna followed by Diptera larvae at the Beech site and by Diplopoda at the Oak and the Cedar sites (Table 3). Three species of earthworms were identified in this study. Allolobophora japonica is widespread in Japan and recognized as a non-specialist species feeding on the surrounding material where they inhabit [32]. Pheretima sp. was classified as a surface dweller by its colour and gut shape (Ishizuka, personal communication). Both species were relatively small with a fresh weight ranging from 0.1 to $0.3 \mathrm{~g}$, and were recorded at ail sampling occasions. The third species, Pheretima acincta is known as a soil dweller [32], therefore it was omitted from the calculation of saprophagous biomass. P. acincta was recorded once in July at the Cedar site with an individual fresh weight of more than $5 \mathrm{~g}$. Although statistically insignificant, on average, the total number of earthworms was highest at the Oak site while their total biomass was highest at the Cedar site.

Few significant differences between sites were found for the density or the biomass of other macrofauna except Diplopoda, which were more abundant at the Cedar site than at the Beech site $(\mathrm{P}<0.01)$. The population size of Collembola was higher at the Oak site than at the Cedar site in May, September and November, and higher than at the Beech site in May and November $(\mathrm{P}<0.05)$. Although statistically insignificant, the estimated total saprophagous biomass tended to be highest at the Cedar site followed by the Oak and by the Beech site (Table 3). 


\section{Discussion}

From litter turnover and decomposition rate, it can be postulated that disappearance of litter is most rapid at the Oak site, followed by the Cedar and the Beech site. Meanwhile, absence of mesh size effect in our litterbag experiments failed to detect the influence of macrofauna on initial litter decomposition and weight loss. Similar results were found in litterbag studies done on moder humus [31,32]. The biomass of saprophagous macrofauna in our study was smaller than that of a moder humus studied by Tsukamoto [32] and lies in the lower range for temperate region reported by Peterson and Luxton [18] and others (Table 3). Therefore, the influence of macrofauna on weight loss in our study sites is assumed to be only minor and the decomposition rate was likely controlled by litter quality.

However, micromorphology demonstrated a difference in faunal feeding activity, mainly from earthworms and Diplopoda. In the Oak site, bleaching of leaves by white-rot fungi was intense near the soil surface but disappeared abruptly underneath, displaying a two-step decay process; fast near surface then slow when reaching deeper horizons. The high frequency of macrofauna activity as shown in leaf grazing, fragmentation and skeletonization, may be enhanced by intense white rot development $[9,12]$. Broad-leaved litter at the Cedar site followed the same non-linear pattern of decomposition, indicating a poor influence of cedar litter on the process of deciduous leaf litter decomposition.

In our experiment, beech litter was poorly influenced by white-rot fungi and decomposed more slowly th an oak litter. The accumulation of faeces between beech leaves forming a sandwich like structure had already been observed by Ponge [20] in Belgium and by Takeda and Kaneko [29] in Japan. The gradual decomposition of beech litter contrasts with the two-step decomposition of oak and other broadleaved species. Slow transformation of beech litter led to the formation of stiff assemblages of litter which cannot be penetrated by macrofauna, only tiny animals such as Enchytraeida, subterranean springtails and mites being able to forage within them. Such structure may have further enhanced the development of thick litter accumulation leading to the formation of relatively large aggregates.

Meanwhile, the pattern of cedar needle decomposition was consistent with a broad range of coniferous studies $[2,4,19,28]$. Leaves could either be eaten by mesofauna tunneling through mesophyll or be nibbled by earthworms. Relatively thick Oe horizon is likely due to the accumulation of faecal materials within rigid epidermis cell of the cedar needle, which collapses only towards the end of needle decomposition. 
Mixing of organic and mineral materials was mostly attributed to earthworms in the Beech site and to earthworms and Diplopoda in the Oak and the Cedar sites. Among earthworm species, mineral ingestion was attributed to A. japonica, which is known as a non-specialist [32]. Mineral materials observed in the Oe horizon of the Cedar site were probably deposited by earthworms, in particular the soil-dwelling P. acincta, which was recorded only at the Cedar site. Diplopoda have also been reported to ingest mineral soil and to inhabit the A horizon [17,32] but with a weaker burrowing activity compared to earthworms.

In contrast to European forests [6], Japanese forests do not seem to support any anecic earthworms, i.e. animals able to feed on both soil and litter. The observed incomplete incorporation of organic and mineral material and the resulting accumulation of organic faeces (Oa horizon) in our three forest sites are probably the consequence of the historical absence of anecic earthworms in Japan [7]. It can be speculated that, provided anecic earthworms with a large ecological amplitude such as Lumbricus terrestris be present, the humus form at the Oak site, where intense saprophagous activity led to a rapid transfer of material from Oe to Oa horizon, would be a mull.

A decoupling between $\mathrm{O}$ and $\mathrm{A}$ horizons was observed at Beech and Oak sites. On one hand litter was incompletely decomposed, leading to the development of Oe or Oa horizons, on the other hand the A horizon underneath showed clues of faunal activity and a crumby structure. This discrepancy may be at least partly explained by the high clay content of the soil [15]. A higher proportion of large aggregates was observed at the Beech site compared to the Oak site. This was probably due to the low level of earthworm activity at the Beech site (Table 3). In the Oak site, a higher proportion of dark-coloured aggregates and a gradual change in colour was observed in the A horizon. This gradient of colouration is probably the result of both biogenic organomineral integration [5] and physical percolation of humic substances.

At the Cedar site, shallow Oa horizon and the relatively thick Oe horizon, and the abrupt transition between an organic O horizon and an organic-poor A horizon were depicted. Such humus form can be explained by incomplete humus development after 45 years of plantation. Although accumulation of needle litter may proceed, the humus profile has a great potential of plant litter decomposition given that deciduous leaves decompose as fast as in the Oak site and saprophagous biomass was relatively high. 
From the distribution of roots and decomposition patterns, we can infer that nutrient turnover is most efficient at the Oak site and least at the Beech site. The Beech site exhibited an important development of fine live roots in the $\mathrm{O}$ horizon, probably in response to an inconsistent nutrient supply.

Optical analysis demonstrated the difference in the transformation pattern of litter and in the extent of faunal activity leading to the different structure of faecal materials in Oe to A horizon under the three sites.

\section{Acknowledgements}

We would like to express our gratitude to members of the Laboratory of Soil Science, Kyoto University, for kind help during fieldwork and valuable discussions. We also wish to thank Mr. L. Bufano for correcting English.

\section{References}

[1] G. Abrahamsen, Studies on body-volume, body-surface area, density and live weight of Enchytraeidae (Oligochaeta), Pedobiologia 13 (1973) 6-15.

[2] U. Babel, Micromorphology of soil organic matter, in: ].F. Gieseking (Ed.), Soil Components, Organic Components, vol. 1, Springer, New York, 1975, pp. 369-473.

[3] L. Bal, Morphological investigation in two moder-humus profiles and the role of the soil fauna in their genesis, Geoderma 4 (1970) 5-36.

[4] L. Bal, Zoological Ripening of Soils, Centre for Agricultural Publication, Wageningen, 1982.

[5] N. Bernier, Earthworm feeding activity and development of the humus profile, Biol. Fertil. Soils 26 (1998) 215-223.

[6] N. Bernier,J.F. Ponge, Humus form dynamics during the sylvogenetic cycle in a mountain spruce forest, Soil Biol. Biochem. 26 (1994) 183-220. 
[7] R.J. Blakemore, Japanese earthworms (Annelida: Oligochaeta): a review and checklist of species, Organ. Divers. Evol. 3 (2003) 241-244.

[8] J.G. Bockheim, E.A. Jespen, D.M. Heisey, Nutrient dynamics in decomposing leaf litter of four tree species on a sandy soil in northwestern Wisconsin, Can. J. For. Res. 21 (1991) 803-812.

[9] O. Daniel, F. Schonholzer, S. Ehlers, J. Zeyer, Microbial conditioning of leaf litter and feeding by the woodlouse Porcellio scaber, Pedobiologia 41 (1997) 397-401.

[10] C.A. Edwards, Relationship between weights, volumes and numbers of soil animals, in: O. Graff, J.E. Satchell (Eds.), Progress in Soil Biology (1967), pp. 585-594 Amsterdam.

[11] A.C. Finzi, N.V. Breemen, D.C. Charses, Canopy tree-soil interactions within temperate forests: species effects on soil carbon and nitrogen, Ecol. Appl. 8 (1998) 440-446.

[12] N. Hafidi, I. Garay, J.P. Cancela da Fonseca, Colonization of brown and bleached litter of a beech forest by edaphic macroparthopods, Pedobiologia 42 (1998) 23-32.

[13] S.E. Hobbie, Effects of plant species on nutrient cycling, Trends Ecol. Evol. 7 (1992) 336-339.

[14] H. Matsumoto, K. Niijima, The decomposition of litter and seasonal changes of soil macrofauna at Pinus densiflora forest and Quercus serrata forest, Bull. For. For. Prod. Res. Inst. 364 (1993) 51-68 (in Japanese).

[15] K. Mori, H. Shinjo, A. Kato, T. Kosaki, Comparison of different soil classification systems using 5 profiles from different forest ecosystems in Japan, Pedologist 49 (2005) 10-21.

[16] S. Nakamura, Amounts of nutrients in litter layer and mineral soil of natural forest on Mt. Sanpou, the Kyushu mountains, Jpn. J. For. Environ. 19 (1987) 50-56 (in Japanese).

[17] K. Niijima, Effects of outbreak of the train millipede Parafontaria laminate armigera Berhoeff (Diplopoda: Xystodesmidae) on litter decomposition in a natural beech forest in Central Japan 1. Density and biomass of soil invertebrates, Ecol. Res. 13 (1998) 41-53.

[18] H. Peterson, M. Luxton, A comparative analysis of soil fauna populations and their role in decomposition processes, Oikos 39 (1982) 287-388. 
[19] J.F. Ponge, Succession of fungi and fauna during decomposition of needles in a small area of Scots pine litter, Plant Soil 138 (1991) 99-113.

[20] J.F. Ponge, Horizons and humus forms in beech forest of the Belgian Ardennes, Soil Sci. Soc. Am. J. 63 (1999) 1888-1901.

[21] J.F. Ponge, Humus forms in terrestrial ecosystems: a framework to biodiversity, Soil Biol. Biochem. 35 (2003) 935-945.

[22] C.E. Prescott, D.M. Preston, Nitrogen mineralization and decomposition in forest floors in adjacent plantations of western red cedar, western hemlock, and Douglas-fir, Can. J. For. Res. 24 (1994) 24242431 .

[23] K. Raulund-Rasmussen, K. Vejre, Effect of tree species and soil properties on nutrient immobilization in the forest floor, Plant Soil 168 (1995) 345-352.

[24] M. Shaefer, J. Schaurman, The soil fauna of beech forest: comparison between a mull and a moder soil, Pedobiologia 34 (1990) 299-314

[25] T. Shidei, T. Kira, Primary Productivity of Japanese Forests. Productivity of Terrestrial Communities JIBP Synthesis, In: Japanese Committee for the International Biological Program, vol. 16, University Tokyo Press, Tokyo, 1977

[26] Soil Survey Division Staff, Soil Survey Manual, USDA, Washington, 1993.

[27] H. Takeda, Interactions between plant and decomposer populations in forest ecosystems - a mechanism of biodiversity maintenance-, Jpn. J. Ecol. 44 (1994) 211-222 (in Japanese).

[28] H. Takeda, A preliminary study on the decomposition and genesis of soil organic layer in a pine forest, Bull. Kyoto Univ. For. 59 (1987) 76-90 (in Japanese).

[29] H. Takeda, N. Kaneko, Patterns of soil humus accumulation in forests. 1. Mull and moder types humus in a broad-leaved forest, Bull. Kyoto Univ. For. 60 (1988) 33-45.

[30] S. Topoliantz, J.F. Ponge, P. Viaux, Earthworm and enchytraeid activity under different arable farming systems, as exemplified by biogenic structures, Plant Soil 225 (2000) 39-51. 
[31] F. Toutain, Les humus forestiers: structures et modes de fonctionnement, Rev. For. Fr. 33 (1981) 449-477.

[32] J. Tsukamoto, Study on the Effect of Soil Macrofauna on the Disappearance of Leaf Litter, PhD thesis, Kyoto Univ., Kyoto, Japan, 1996.

[33] J. Uchida, An investigation of the forest humus layers of the needle-leaved forest in Hokkaido, Bull. Government For. Exp. Stn. 114 (1959) 53-205. 


\section{Legends of figures}

Fig. 1. Vertical distribution of humus components grouped into broad categories in the three study sites.

Fig. 2. a-r Some humus components found in the studied profiles. a) Smear-like earthworm faeces on a beech leaf From the Oi horizon. b) A cross-section of a beech leaf from the upper Oe horizon. Melanized fungal hyphae run on upper and lower surfaces of the beech leaf. Leaf browning substances were observed in the mesophyll. c) Fragmented litter from the lower Oe horizon in the Oak site. d) Blackened cedar needles from the upper Oe horizon. Some needles are nibbled by earthworms. e) Cross-section of a cedar needle from the Oi horizon. The leaf is covered by a cuticular layer, which was partly detached. Melanized hyphae are observed on the needle surface. Fungal hyphae were also embedded in the epidermis cells. f) Cross-section of a cedar needle from the upper Oe horizon. Melanized hyphae are observed in free spaces of the mesophyll and along phloem cells. g) Sandwich-like structure from the middle part of the Oe horizon. Faeces accumulate between undecomposed beech leaves. h) Crosssection of a sandwich-like structure showing accumulation of faecal material of various mesofauna, coalesced and accumulated between undecomposed beech leaves. Many roots were observed passing through the structure. i) Cross-section of a compact sandwich-like structure from the lower Oe horizon in the Beech site. Leaf fragments of various size are included in the structure. j) Compact organic aggregate from the lower Oe horizon in the Beech site. Leaves have mostly disappeared. k) Organic aggregate from the lower Oe horizon in the Beech site, heavily penetrated by roots. 1) Intact earthworm faeces from the upper A horizon in the Beech site. The cast is mainly organic but is also comprised of mineral matter. m) Cross-section of an earthworm faeces from the A horizon in the Beech site. Organic and mineral matter are juxtaposed but not intimately mixed. n) Organo-mineral aggregate (earthworm faeces) from the A horizon in the Beech site. Part of the aggregate is excavated by enchytraeids, which deposit their faeces on the surface. o) Cross-section of Fig. 2n. Cross-polarization reveals that the matrix is mainly mineral but the darker part is richer in organic matter. In the middle part, faeces of enchytraeids are observed. p) Cross-section of an organic faeces from the upper Oa horizon in the Oak site. Mostly well-comminuted and degraded organic matter with a small amount of mineral matter. q) 
Organic faeces from the lower Oa horizon in the Oak site. Well-comminuted plant material in the upper part and recognizable leaf tissues in the lower part. r) Cross-section of a cedar needle from the middle Oe horizon in the Cedar site. Mesophyll was mostly grazed by oribatid mites, which deposit their faeces inside cedar needles.

Fig. 3. Vertical distribution of leaf and needle litter components in the three study sites. For the Cedar site, cedar needle and all the other deciduous leaf litter are shown separately.

Fig. 4. Vertical distribution of faeces and aggregate components in the three study sites.

Fig. 5. Vertical distribution of organic faecal and organo-mineral components of Oa and A horizons in the three study sites according to their size. $\mathrm{X}$ axis is percentage against total organic faecal and organo-mineral components.

Fig. 6. Vertical distribution of tree root components in the three study sites. Oi horizon is not shown since no root was found in this horizon in all sites 
Table 1. Broad and detailed categories recorded for the description of a humus profile.

\begin{tabular}{|c|c|c|}
\hline Borad categories & Detailed categories & Descriptions \\
\hline \multirow[t]{10}{*}{ Leaves } & & Leaf of trees and dwarf bamboo \\
\hline & Brown leaf $^{a}$ & Leaf of deciduous trees whose surface colour is brown without consipicuous colour changes \\
\hline & Variegated leaf & Leaf of deciduous trees whose surface colour is partly lightened \\
\hline & Bleached leaf & Leaf of deciduous trees whose colour is bleached \\
\hline & Grazed and skeletonized leaf & Leaf of deciduous trees grazed by soil fauna or skeletonized due to faunal attack \\
\hline & Vein or petiole & Vein or petiole of deciduous tree leaf \\
\hline & Brown needle & Freshly fallen brown cedar needle \\
\hline & Blackened needle ${ }^{\mathrm{a}}$ & Blackened cedar needle \\
\hline & Light-coloured needle & Light-coloured cedar needle with thinning of the epidermis by microbial attack \\
\hline & Grazed needle & Cedar needle grazed by soil fauna \\
\hline \multirow{6}{*}{ Organic faecal materials $^{\mathrm{a}}$} & Enchytraeid faeces & Enchytraeid faeces, organic or organo-mineral ${ }^{b}$ \\
\hline & Earthworm faeces & Earthworm faeces, organic or organo-mineral ${ }^{b}$ \\
\hline & Other macrofauna faeces & Other macrofauna faeces, either organic or organo-mineral ${ }^{\mathrm{b}}$ \\
\hline & Organic faeces & Organic faeces, brown with medium to coarse texture, not attributed to a particular taxonomic group \\
\hline & Dark coloured organic aggregates & Organic aggregates, dark brown to blackish with fine texture \\
\hline & Compact organic aggregates & Aggregates similar as above but more compact in structure \\
\hline \multirow[t]{3}{*}{ Organo-mineral materials ${ }^{\mathrm{a}}$} & Dark-coloured organo-mineral aggregates & Organo-mineral aggregates, dark coloured \\
\hline & Light-coloured oprgano-mineral aggregates & Organo-mineral aggregates, light-coloured \\
\hline & $\begin{array}{l}\text { Compact organo-mineral aggregates with } \\
\text { mineral grains }\end{array}$ & Organo-mineral aggregates with a compact structure and mineral grains \\
\hline \multirow[t]{5}{*}{ Roots } & Living fine roots & Living roots of tree or sasa with diameter less than $0.5 \mathrm{~mm}$ \\
\hline & Dead fine roots & Dead roots of trees or sasa with diameter less than $0.5 \mathrm{~mm}$ \\
\hline & Living coarse roots & Living roots of trees or sasa with diameter more than $0.5 \mathrm{~mm}$ \\
\hline & Dead coarse roots & Dead roots of trees or sasa with diameter more than $0.5 \mathrm{~mm}$ \\
\hline & Ectomycorrhiza & Roots with ectomycorrhiza \\
\hline Other plant materials & & Miscellaneous plant litter \\
\hline \multicolumn{3}{|l|}{ Micellaneous materials } \\
\hline & & Mycelial strands, soil fauna and remains of soil fauna, and unidentified material \\
\hline
\end{tabular}

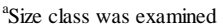

${ }^{\mathrm{b}}$ Grouped in organic faecal material or organo-mineral material according to broad categories 
Table 2. Measurements on aboveground vegetation and liiter fall, accumulation, and decay.

\begin{tabular}{|c|c|c|c|c|}
\hline \multicolumn{2}{|l|}{ Site } & Beech & Oak & Cedar \\
\hline \multicolumn{5}{|c|}{ Aboveground vegetation } \\
\hline \multicolumn{2}{|c|}{ Total biomass $\left(\mathrm{t} \mathrm{ha}^{-1}\right)$} & 168 & 208 & 369 \\
\hline \multicolumn{2}{|c|}{ Litterfall $\left(\mathrm{t} \mathrm{ha}^{-1} \mathrm{yr}^{-1}\right)$} & 5.0 & 4.6 & 5.2 \\
\hline \multicolumn{2}{|c|}{ Litter accumulation $\left(\mathrm{t} \mathrm{ha}^{-1}\right)$} & 57.9 & 19.4 & 44.1 \\
\hline \multicolumn{2}{|c|}{ Litter turnover rate $\left(\mathrm{yr}^{-1}\right)$} & 0.09 & 0.24 & 0.12 \\
\hline \multicolumn{5}{|c|}{ Decay constant of litterbags for different mesh size } \\
\hline \multirow[t]{2}{*}{ Beech } & coarse & 0.31 & 0.34 & 0.34 \\
\hline & fine & 0.40 & 0.36 & 0.35 \\
\hline \multirow[t]{2}{*}{ Oak } & coarse & 0.48 & 0.50 & nd \\
\hline & fine & 0.51 & 0.50 & nd \\
\hline \multirow[t]{2}{*}{ Cedar } & coarse & nd & nd & 0.39 \\
\hline & fine & nd & nd & 0.35 \\
\hline
\end{tabular}

nd, not determined 
Table 3. Estimated dry biomass of saprophagous soil fauna which likely contribute to the litter decomposition or transformation, presented with some environmental data and litter turnover rate.

\begin{tabular}{|c|c|c|c|c|c|c|c|c|c|c|c|}
\hline \multirow{2}{*}{$\begin{array}{l}\text { Location } \\
\text { Plot }\end{array}$} & \multicolumn{3}{|c|}{ This study } & \multicolumn{2}{|c|}{ Ashu, Japan ${ }^{\mathrm{a}}$} & \multicolumn{2}{|c|}{ Saitama, Japan ${ }^{\mathrm{b}}$} & \multicolumn{2}{|c|}{ Germany $^{c}$} & \multicolumn{2}{|c|}{ Temperate $^{\mathrm{d}}$} \\
\hline & Beech & Oak & Cedar & $\mathrm{R}$ & B & $\mathrm{P}$ & $\mathrm{O}$ & so & GO & Mor & Mull \\
\hline Vegetation & Beech & Oak & Cedar & Beech, oak & Oak, beech & Red pine & Oak & Beech & Beech & Temp & deciduous \\
\hline Mean annual temperature $\left({ }^{\circ} \mathrm{C}\right)$ & 10 & & & 13 & 13 & 13.3 & 13.3 & 5.9 & 7 & & \\
\hline Mean annual precipitation (mm) & 1753 & & & 2493 & 2493 & 1022 & 1022 & 1063 & 700 & & \\
\hline Type of humus form & Moder & Moder & Moder & Moder & Acid mull & & & Moder & Mull & Mor & Mull \\
\hline $\mathrm{pH}$ of the surface soil & 3.8 & 4.2 & 4.1 & 3.8 & 4.5 & & & 3-4 & 5.8 & & \\
\hline Litterfall $\left(\mathrm{g} \mathrm{m}^{-2} \mathrm{yr}^{-1}\right)$ & 488 & 454 & 526 & 320 & 410 & 529 & 460 & 423 & 310 & & \\
\hline Mass of $\mathrm{O}$ horizon $\left(\mathrm{g} \mathrm{m}^{-2}\right)$ & 5792 & 1940 & 4292 & 3332 & 769 & 1384 & 817 & 3710 & 550 & & \\
\hline Litter turnover $\left(\mathrm{yr}^{-1}\right)$ & 0.08 & 0.23 & 0.12 & 0.10 & 0.53 & 0.38 & 0.56 & 0.11 & 0.56 & & \\
\hline \multicolumn{12}{|c|}{ Estimate of biomass of saprophages $\left(\mathrm{mg} \mathrm{m}^{-2}\right)$} \\
\hline \multicolumn{12}{|l|}{ Macrofauna } \\
\hline Oligochaeta & 61 & 112 & 315 & 74 & 226 & 444 & 764 & 168 & 10700 & 220 & 5300 \\
\hline Diplopoda & 8 & 65 & 109 & 141 & 226 & 300 & 193 & 0 & 618 & 420 & 420 \\
\hline Crustacea & 2 & 11 & 10 & 133 & 550 & 10 & 38 & 0 & 47 & 0 & 0 \\
\hline Lepidoptera & 3 & 11 & 1 & 21 & 18 & 1 & 0 & 0 & 0 & 0 & 0 \\
\hline Diptera & 18 & 6 & 5 & 89 & 113 & 6 & 151 & 502 & 120 & 264 & 264 \\
\hline Gastropoda & & & & 0 & 0 & & & 0 & 430 & 270 & 270 \\
\hline Elateridae larvae & & & & & & & & 706 & 104 & & \\
\hline Total macrofauna & 92 & 206 & 439 & 458 & 1133 & 759 & 1146 & 1345 & 11867 & 1174 & 6254 \\
\hline \multicolumn{12}{|l|}{ Mesofauna } \\
\hline Collembola $^{\mathrm{e}}$ & 43 & 78 & 45 & 56 & 22 & & & 123 & 77 & 65 & 55 \\
\hline Cryptostigmata $^{\mathrm{e}}$ & 134 & 122 & 113 & 78 & 38 & & & 98 & 90 & 350 & 90 \\
\hline Enchytraeidae & 129 & 123 & 116 & & & & & 1230 & 450 & 323 & 323 \\
\hline
\end{tabular}

afrom Tsukamoto (1996)

${ }^{\mathrm{b}}$ from Matsumoto and Niijima (1993)

'from Schaefer and Schauermann (1990)

dfrom Peterson and Luxton (1982)

${ }^{\mathrm{e}}$ mean of four sampling occasions in the year 1998 


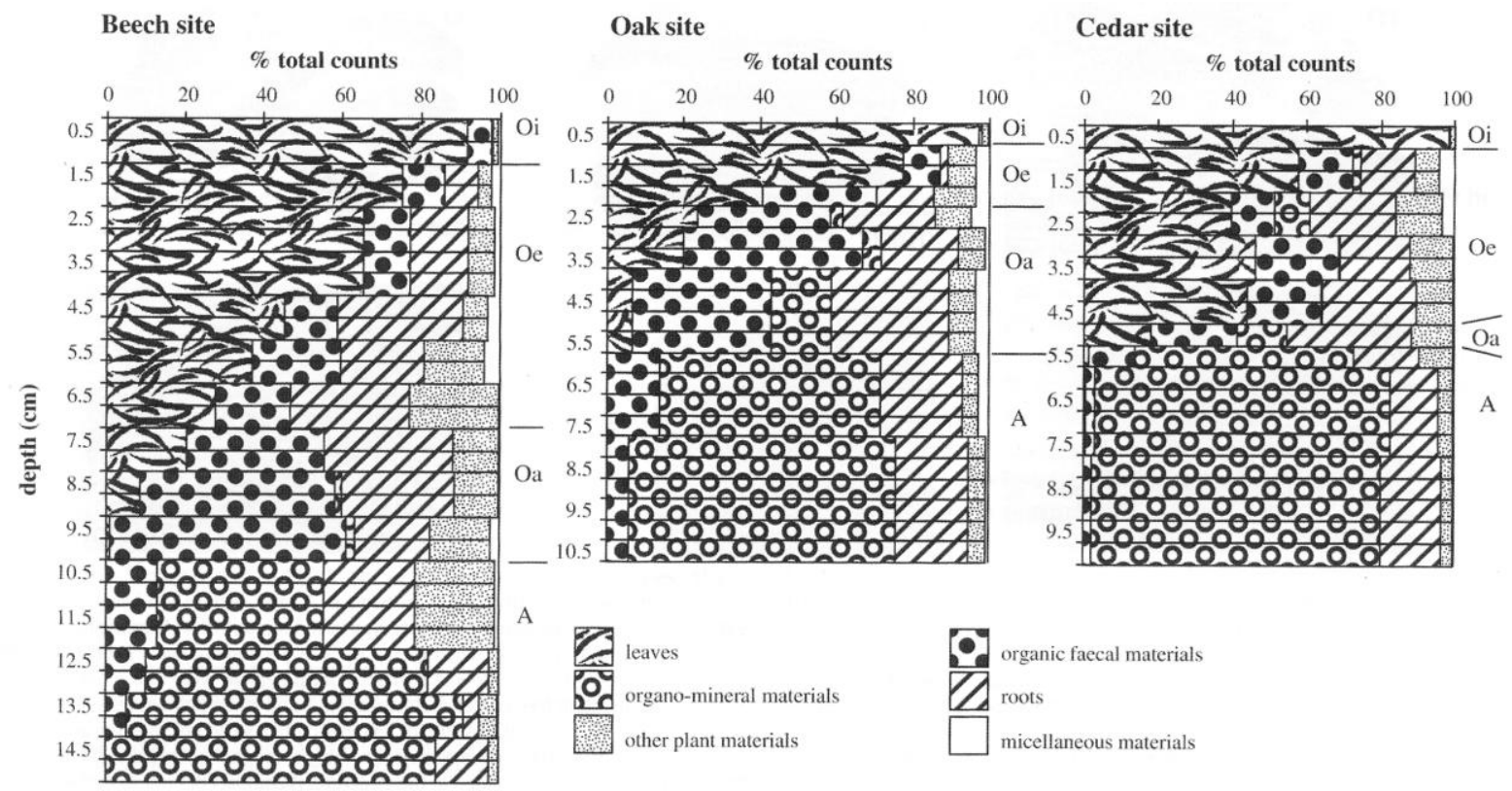

Fig. 1 

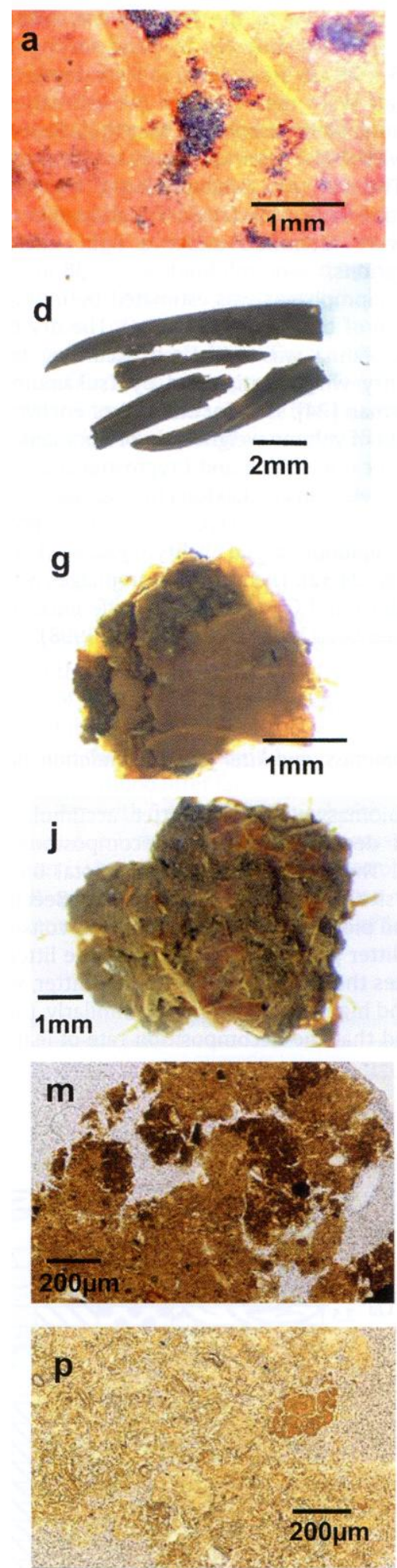
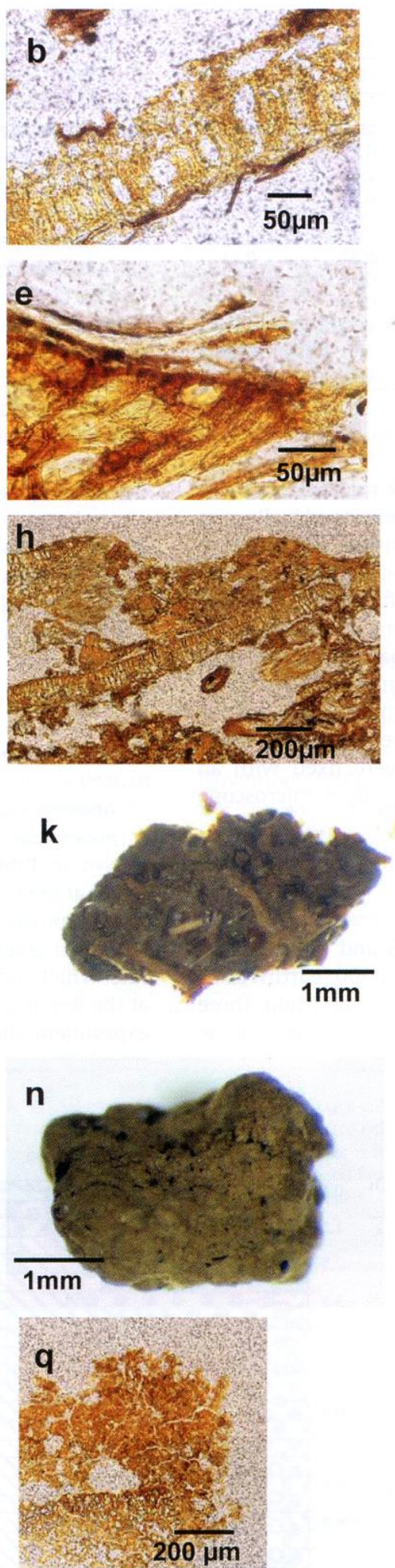
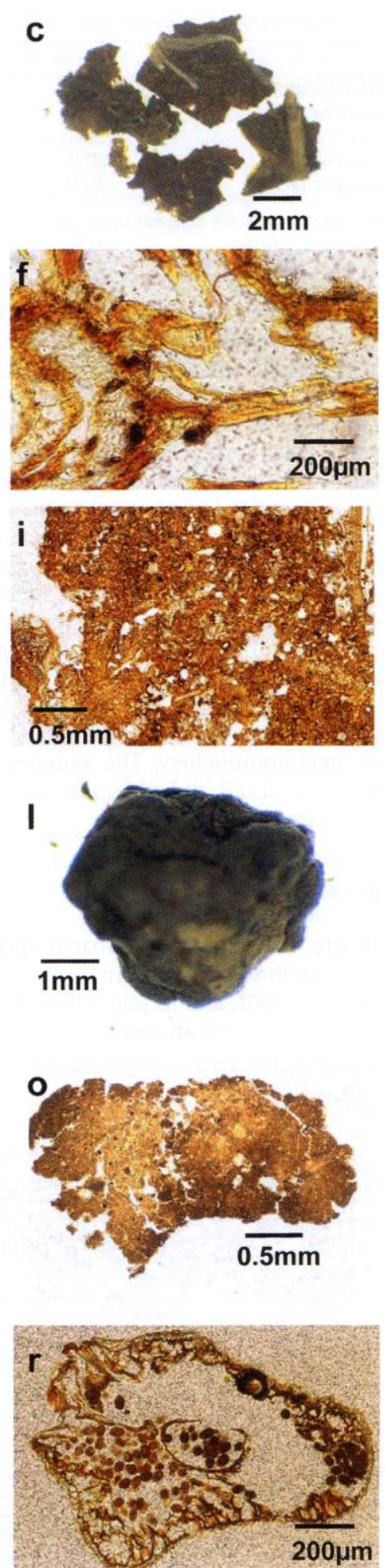

Fig. 2 
Beech site

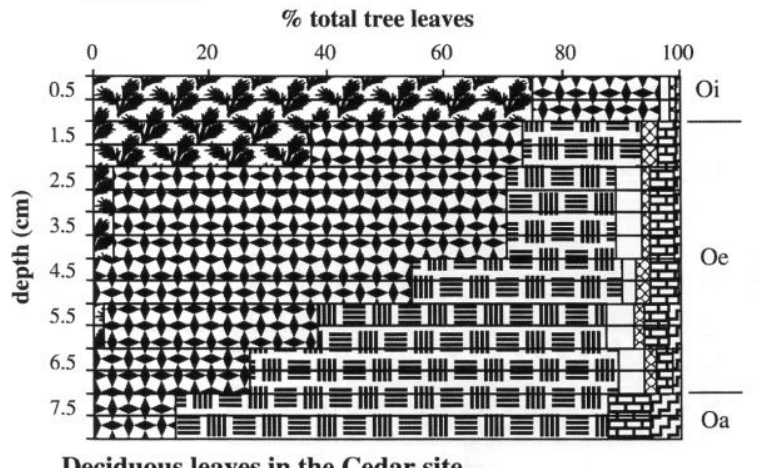

Deciduous leaves in the Cedar site

$\%$ total tree leaves

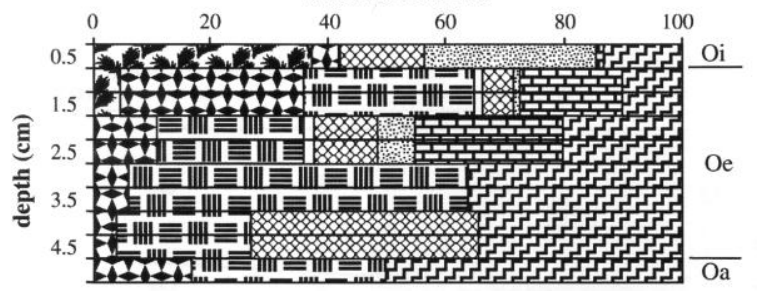

Cedar leaves in the Cedar site

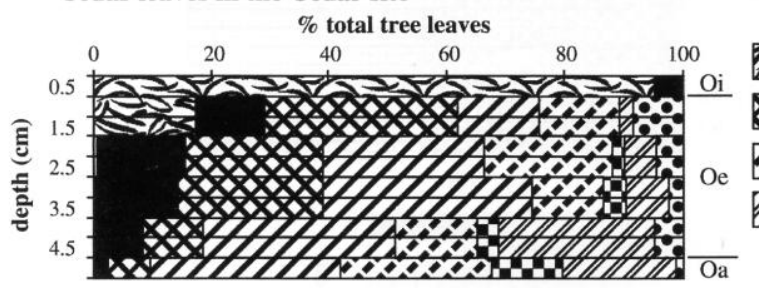

Oak site

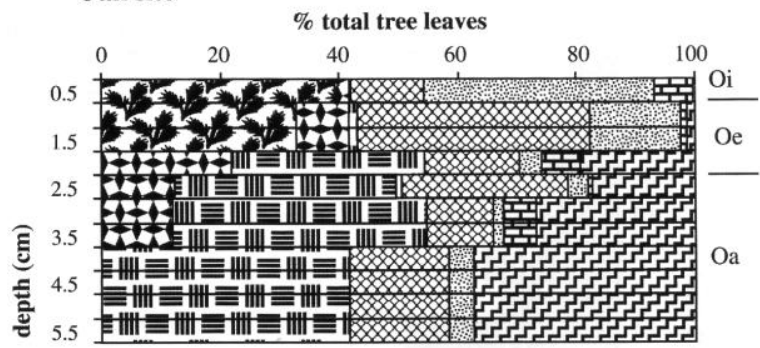

Deciduous leaves

brown leaves of $>10 \mathrm{~mm}$

[7] brown leaves of $2.4-10 \mathrm{~mm}$

EIIII brown leaves of $<2.4 \mathrm{~mm}$

$\square$ unknown size

variagated leaves

bleached leaves

臣 grazed and skeltonized leaves

Fin vein and petiol

\section{Cedar needle}

brown cedar needles

blackened, loose entire

blackened, broken $<3 \mathrm{~mm}^{*}$

Dlight colored needles

blackened needles, intact
blackened, broken $>3 \mathrm{~mm}^{*}$
blackened, fragmented*
grazed needles

Fig. 3 

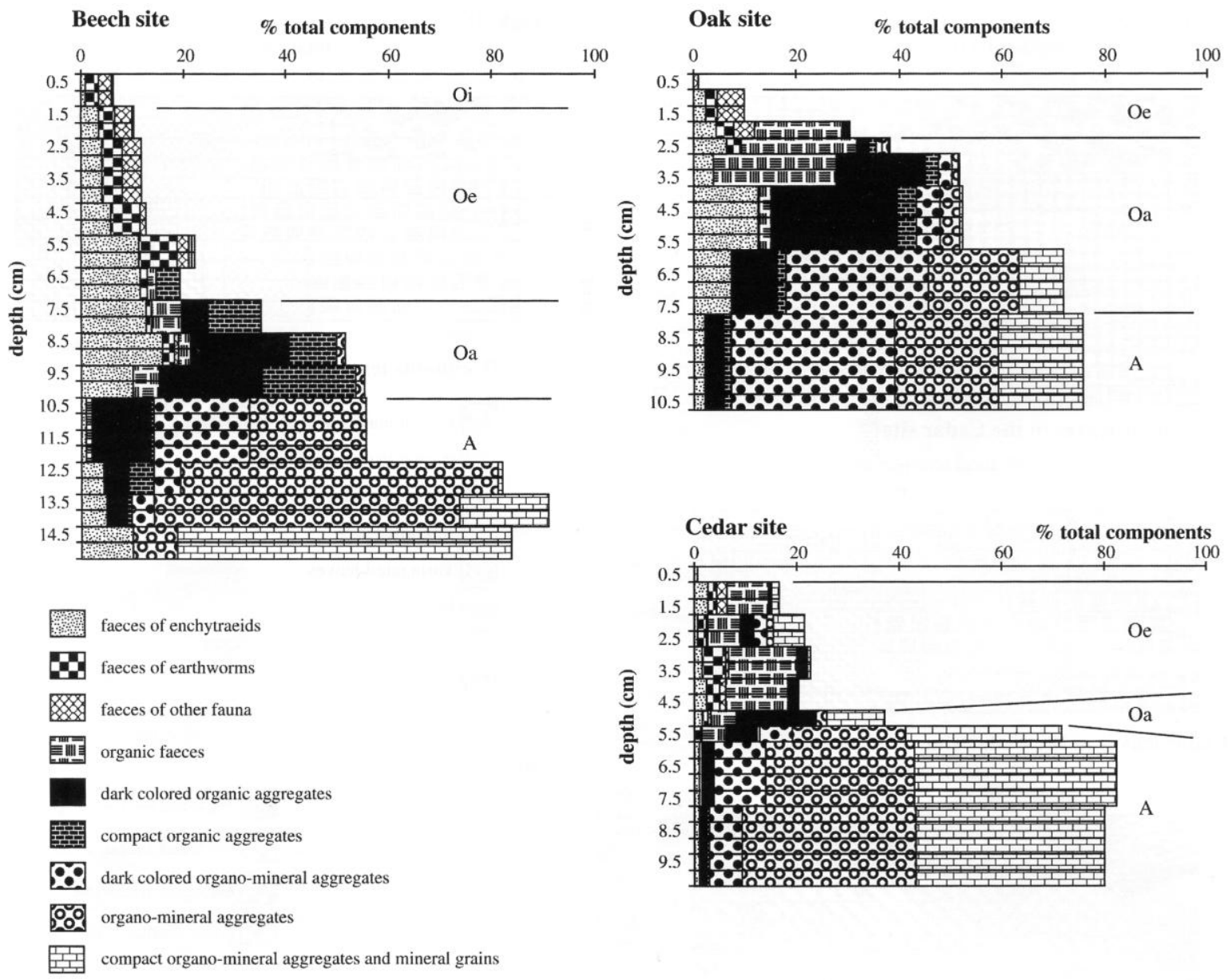

Fig. 4 


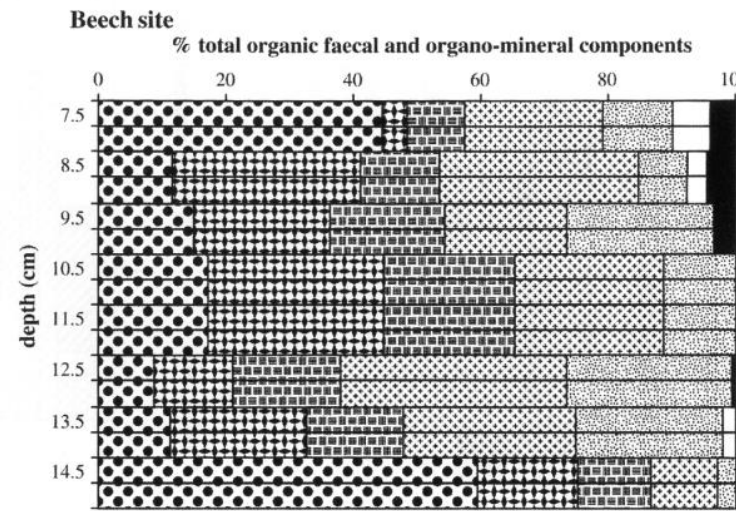

Cedarsite

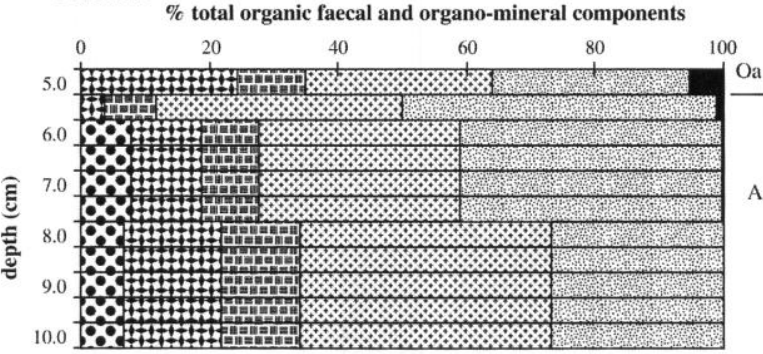

Oak site

$\%$ total organic faecal and organo-mineral components

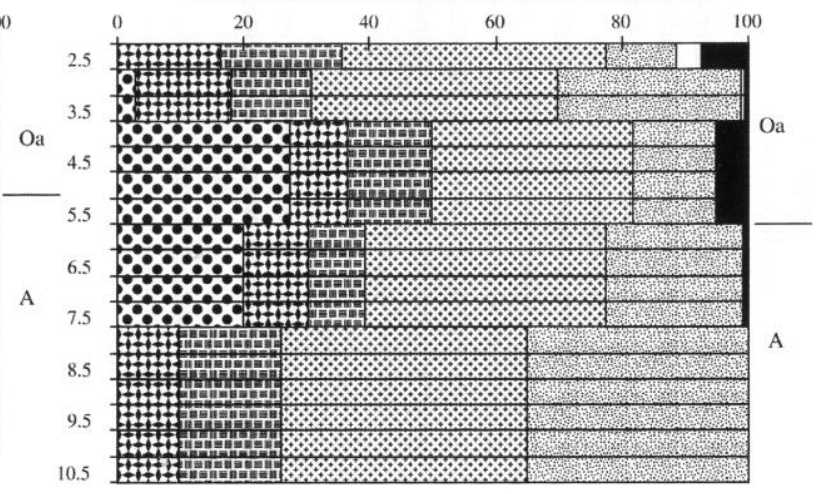

faeces/agregats $>10 \mathrm{~mm}$

fyat faces/aggregats of 4.8-10 mm

faeces/aggregats of $2.4-4.8 \mathrm{~mm}$

F

faeces/aggregats of $<0.6 \mathrm{~mm}$

faeces/aggregats of unknown size

faeces on plants

Fig. 5 


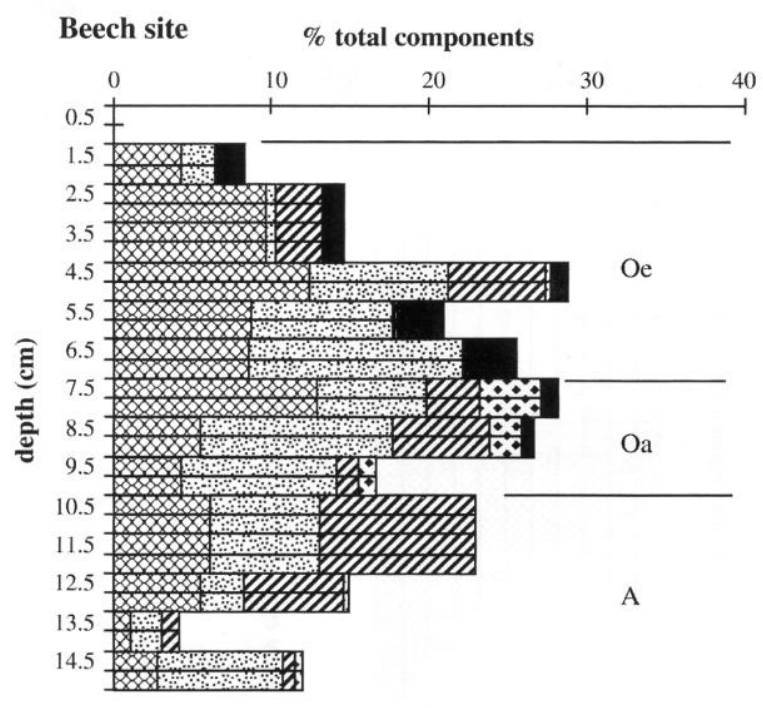

live fine tree root, $<0.5 \mathrm{~mm}$

dead fine root, $>0.5 \mathrm{~mm}$

OIIA live coarse tree root, $<0.5 \mathrm{~mm}$

$\because \%$

dead coarse tree root, $>0.5 \mathrm{~mm}$

Mycorrhiza
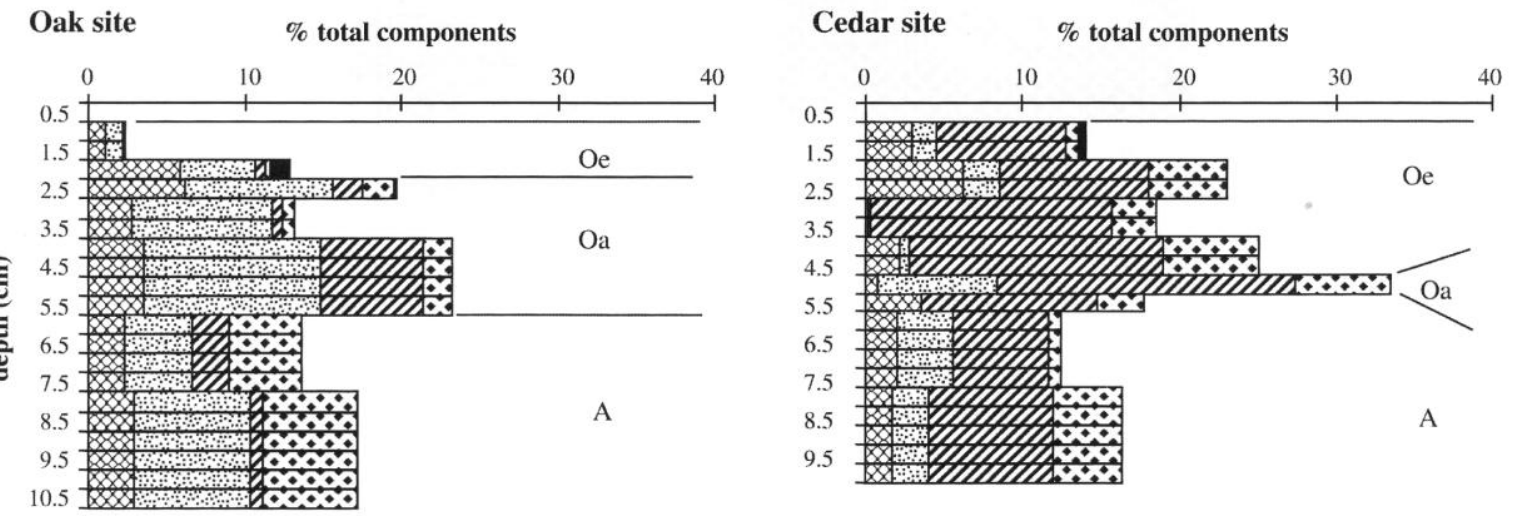

Fig. 6 